\title{
LXXIII. On repeating circles
}

\section{Baron de Zach}

To cite this article: Baron de Zach (1823) LXXIII. On repeating circles, Philosophical Magazine Series 1, 61:301, 353-363, DOI: 10.1080/14786442308644336

To link to this article: http://dx.doi.org/10.1080/14786442308644336

$$
\text { 曲 Published online: } 29 \text { Jul } 2009 .
$$

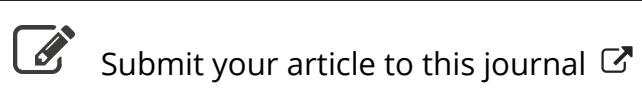

\footnotetext{
Џll Article views: 2
}

Q View related articles $₫$ 
slightly impregnated with sulphate of iron, and had a trace of muriatic acid; and that from the latter mine contained a very minute portion of the muriate of lime."

Mr. Fox terminates this paper with the following additional notice:-

"Since my last communication on the subject of the temperature of mines, I have had a thermometer, four feet long, placed in a hole three feet deep, in a copper vein, at the end of the deepest level, or gallery, in Dolcoath, which is 230 fathoms, or 1380 feet, under the surface : a spot where no workmen were employed, and where the current of air must have been small. The hole was filled with clay round the stem of the thermometer, so as to prevent the circulation of air near the bulb, and in thís situation it remained more than eight months. It was often examined during that period, and was always found to indicate a temperature of $75^{\circ}$, or $75 \frac{1}{2}$, unless it had recently been overflowed by water. This happened several times, in consequence of accidents to the machinery of the mine, and more than once the water filled the level for some weeks. As soon as it had subsided, so as to permit access to the thermometer, the quicksilver was observed to have risen to $77^{\circ}$, but in two or three days it again fell to $75 \frac{1}{2}{ }^{\circ}$."

\section{On Repeating Circles. By the Baron de ZACH.*}

Genoa, January 1, 1823.

WHEN M. Schwerd said in his work entitled La petite Base de Spire, \&c. which we noticed in page 201 of the 7th volume of this Correspondance, "that according to the opinion of astronomers, the zenith distance of a star, observed with the best repeating circles, could not, even after many thousand repetitions, be determined and depended upon to a second ;" we added in a note, "We may affirm yet further, that this uncertainty extends to four seconds."

We did not exaggerate in this assertion; on the contrary, these differences in the zenith distances, observed with the best repeating circles, have more and more exceeded the limit we had assigned to them. This has been the case in the most delicate operations it was possible to undertake; those in which the greatest care and the utmost precautions were necessarily employed. The most important and expensive operation of this kind which has been undertaken, is that which was exe cuted in France in 1792, and two following years, for measuring an arc of the meridian from Dunkirk to the Balearic islands,

* From Zach's Correspondance Astronomique, vol. viii. page 3.
Yol. 61. No. 301. May 1823.
Y y
Both 
Both the astronomical and the geodetical departments were furnished with repeating circles of 13 or 14 inches diameter, constructed by the most celebrated instrument makers of Paris. Let us see to what degree of precision the most skilful observers found it possible to attain with such instruments.

In the second volume of the "Base du Système métrique," will be found all the observations of latitude made with these circles upon several points of this great meridian. Let us hear the declarations of the observers themselves.

M. Delambre, after relating, page 26\%, the observations which he made at Dunkirk of the zenith distance of the star $\beta$ Ursa Minoris, at its upper culmination, adds the following remarks :

"This second series of observations of the passage of $\beta$ Ursa Minoris, presents singularities whose cause it is difficult to ascertain. If it cannot serve to determine the latitude of Dunkirk, it will at least not be useless as a history of the repeating circle. I think it therefore my duty to lay it before the public. Up to the $2 \mathrm{~d}$ and $3 \mathrm{~d}$ of March, the series presented nothing extraordinary. On the 4th the observations appeared very good ; they however gave a latitude $24^{\prime \prime}$ in excess, which can only be explained on the supposition that some derangement of the glasses had taken place. On the 7 th, the latitude was $10^{\prime \prime}$ in defect, although the observations appeared very satisfactory; excepting only, that I thought I perceived something extraordinary in the clamp. After the series, M. Bellet examined this clamp, but could discover nothing unusual about it."

M. Delambre, after saying that he had endeavoured with all possible care to discover the cause of these inequalities, after having exhausted every possible conjecture and hypothesis, confesses, nevertheless, that all these explanations are far from appearing satisfactory to him, and concludes by saying, "that the safest conclusion he could come to, was to reject the series altogether;" a series which consists of more than 200 observations, made from the 2d to the 18th of March, 1796. He adds at the end (p. 264), "These are the only reasons for failure which I have been able to imagine, and none of them satisfy me. Though these inexplicable anomalies have tormented me extremely during a whole month, I could never believe that they arose from unskilfulness; and my confidence on this head has been confirmed by the example of M. Méchain."

In fact, M. Méchain was not more fortunate in his explanations of the cause of these irregularities, of which he remarked as great a number as M. Delambre. This is sufficiently 
ficiently evident from the confessions he made in his letters to M. Borda, the inventor, and consequently the ardent partisan, of the circles which bear his name.

In one of his letters deposited in the Royal Observatory at Paris, he writes as follows :-

"I send you tables of the results of my cursed observations of the pole-star, and of $\beta$ Ursa Minoris. You will see abundant proofs that I am incapable of making observations of latitude even passable; I am in despair at it. The pole-star was observed with one of two circles; $\beta$ Ursa Minoris with the other. I used as much care as heretofore, and even more; the verticality of the circle was verified every day; the level proved that it did not vary half a minute in the course of a day's observation.

"The position of the vernier was inspected every time before we began, to see that it had not changed since the last observation; the level was adjusted with every possible precaution; I pointed to the star with all the accuracy of which I am master; never did I take so many precautions, and never did I succeed so ill. I turned the circle again and again in all directions; I examined all the pieces; I tried to discover the cause of these monstrous discordances, and I could discover nothing, although I consumed an infinity of time about it. It is then, evidently, my awkwardness. I was greatly distressed when the results of one day differed from those of another by 1 " or $2^{\prime \prime}$, though this is a degree of precision not always attained with an excellent mural circle of eight feet, and not exceeded in zenith distances for the measurement of degrees made with the best and the largest sectors.

"In the present case, I presumed that a small number of observations above and below the pole, would not leave me an uncertainty of more than two or three tenths of a second. So far am I from realizing these expectations, that I have deviations of $10^{\prime \prime}$, and the mean of the first series differs from the mean of the second. I have lost all my time in revising and calculating these observations; and after having neglected another undertaking in the hope of accomplishing this, I have obtained nothing but the certainty of the worst possible success."

M. Delambre adds still further (p. 270), "What then happened to him (M. Méchain) had happened to me four times at Dunkirk; and although I did not distress myself like him, I had, like him, redoubled my precautions against failure. In relating his own history he relates mine, and our example may console other astronomers who may experience similar disappointments."

It must be confessed, that however consolatory this may be

$$
\text { Y y } 2
$$


to astronomers, it is not very satisfactory so far as the interests of the science are concerned. Let us now take into consideration the results of all these observations, and let us remark the greatest differences between the zenith distances which have been observed, and we shall have the following table:

Observations at Dunkirk by M. Delambre :

\begin{tabular}{|c|c|c|c|}
\hline \multirow{4}{*}{ By the pole-star upper culm. } & \multirow{4}{*}{$\begin{array}{l}\text { Greatest } \\
\text { Differ. } \\
6, " 00 \\
7,09\end{array}$} & \multirow{3}{*}{$\begin{array}{c}\text { Number } \\
\text { of Obs. } \\
154\end{array}$} & \multirow{2}{*}{$\begin{array}{l}\text { Base du } \\
\text { Syst. Mét. } \\
\text { Vol. II. }\end{array}$} \\
\hline & & & \\
\hline & & & p. 276 \\
\hline & & 200 & \\
\hline $1 *$ & 36,48 & 144 & p. 292 \\
\hline & & 66 & p. 293 \\
\hline
\end{tabular}

At the observations of $\beta$ Urs $\alpha$ Minoris, at its upper culmination, in which the enormous difference of $36^{\prime \prime}$ occurs, M. Delambre adds the following remark:

"I reject four series evidently defective, although I could not discover with incontestable certainty what rendered them so bad." Bad indeed, for on the 4th of March he found by 16 observations the latitude $=51^{\circ} 2^{\prime} 40^{\prime \prime}, 72$, and three days after, on the 7 th, he found it, by 14 observations, $=52^{\circ} 2^{\prime} 4^{\prime \prime}, 36$. The real latitude is $52^{\circ} 2^{\prime} 15^{\prime \prime}$.

At Paris, in his observatory in the Rue de Paradis, M. Delambre found the following differences:

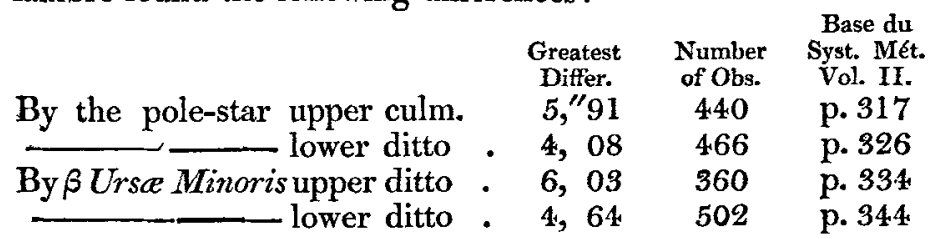

M. Méchain, though more adroit and more experienced than M. Delambre, was not more fortunate in his observations, or in the results he obtained. His observations were made at the Royal Observatory at Paris. He began by suppressing more than 800 observations of the upper culmination of the pole-star, made in the interval between the 9th of December 1798 and the 6th of February 1799, and more than 400 of the lower culmination of $\beta$ Urs $x$ Minoris, made during the same period. He had also observed the upper culmination of that star, as well as the lower culmination of the pole-star; but these observations could never be found. M. Méchain has therefore rejected more than 2000 observations. We may easily guess what sort of agreement they would have exhibited, since we know the reasons which induced this able, patient and sincere astronomer to reject them. This, however, is the very cause of our regret. 
M. Méchain continued to make observations at the Royal Observatory. In the months of July and August, 1799, he observed the pole-star at its upper culmination, and in May and June at its lower culmination; as also $\beta$ Ursa Minoris at its upper culmination, and in August and September at its lower culmination. His tables give the following differences:

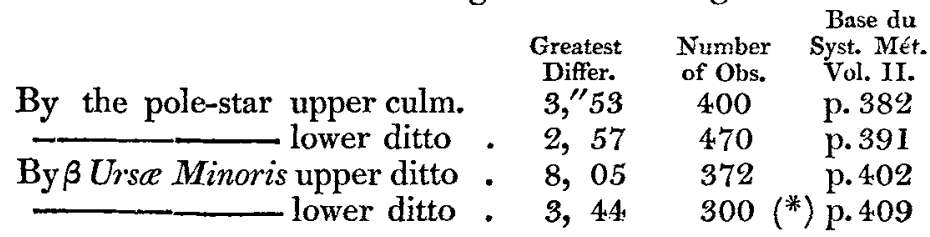

Towards the end of the year 1796, M. Delambre set out for Evaux. He there observed the zenith distances of the same stars, with the same circles with which he had observed them at Paris. His greatest differences then were:

\begin{tabular}{|c|c|c|c|}
\hline By the pole-star upp & $\begin{array}{c}\text { Greatest } \\
\text { Differ. } \\
7, " 35\end{array}$ & $\begin{array}{c}\text { Number } \\
\text { of Obs. } \\
210\end{array}$ & $\begin{array}{l}\text { Base du } \\
\text { Syst. Mét.t. } \\
\text { Vol. II. } \\
\text { p. } 464 \\
\text {. }\end{array}$ \\
\hline $\begin{array}{l}\text { By } \beta \text { Urse Minoris upper ditto } \\
\text { lower ditto }\end{array}$ & $\begin{array}{l}8,00 \\
8,33 \\
8,79\end{array}$ & $\begin{array}{l}410 \\
326 \\
276\end{array}$ & $\begin{array}{l}\text { p. } 463 \\
\text { p. } 470 \\
\text { p. } 471\end{array}$ \\
\hline
\end{tabular}

We see here that the differences, according to M. Delambre, are much greater than those of M. Méchain at Paris. Does this arise from the superior skill of this able astronomer, or from his choosing those of his observations amongst which there existed the greatest agreement? It is impossible not to suspect this, since he rejects observations by thousands. We will also point out to our readers that $\mathbf{M}$. Delambre frequently uses the following expression; as for instance, page 441, "When I tried to unscrew the clamp, I found that it had loosened of itself." This happened to him twice in five days, and we are much astonished at it ; for we have no idea how in an uninterrupted series of cross observations, such a clamp can loosen itself after having been well screwed; at least, such an accident has never occurred to us.

M. Méchain was requested to go to Evaux to make observations conjointly with M. Delambre ; but this he always refused to do. M. Borda wrote to him from Paris, "I cannot

* Errors of calculation frequently occur. For instance (p. 407), the observation of $\beta$ Urse Minoris at its lower culmination, on the 9th of Sept. 1799 , gives as the true latitude $48^{\circ} 50^{\prime} 14,,^{\prime \prime} 31$; in the book it is marked $48^{\circ}$ 50 16," 23 . Many similar errors would be found on a revision of the calculations. 
see why you will not make observations at Evaux conjointly with Delambre" (p. 624). We know perfectly well the reason of this repugnance.

In the beginning of the year 1797, M. Méchain went to make observations at Carcassonne. He made but few. M. Delambre thinks that, in fact, he suppressed them. He says, (p. 479,) "It is very improbable that M. Méchain passed all the time from the 17th of January to the 20th of March in idleness; we can only suppose that he communicated to us only those observations with which he was fully satisfied, and unmercifully proscribed all the others for some irregularities which would, perhaps, have rendered them precious for the theory of refractions. It is particularly extraordinary that he should not once have attempted to observe $\beta$ Ursc Minoris." He did, no doubt, attempt it; but he probably destroyed those observations which never satisfied him. He was always persuaded that those which he made with those cursed repeating circles (for so he called them in the society of his friends), were good for very little; but this duty was forced upon him. At Carcassonne, then, he made only observations of the pole-star, which gave

$\begin{array}{cccc} & \begin{array}{c}\text { Greatest } \\ \text { Differ. }\end{array} & \begin{array}{c}\text { Number } \\ \text { of Obs. }\end{array} & \begin{array}{c}\text { Base du } \\ \text { Syst. Mét. } \\ \text { Vol. II. }\end{array} \\ \text { At its upper culmination....... } & 1, " 93 & 200 & \text { p. } 488 \\ \text { At its lower culmination...... } & \mathbf{1 , 9 3} & \mathbf{2 3 4} & \text { p.488 }\end{array}$

In the month of July, 1796, M. Méchain went to Perpignan, and observed there only the zenith distances of one star, $\beta$ Ursce Minoris, and that only at its upper culmination. M. Delambre says (p. 493), that he has never been able to find the originals of these observations, and that he has been obliged to take them entirely from copies of the calculations of the latitude. The result is, that in 152 observations of that star, the greatest difference was $6^{\prime \prime}, 81 .-$ (P. 502.)

In 1793 and 1794, M. Méchain was in Spain. He made observations in the city of Barcelona, and in the citadel of Montjouy. He took with him two repeating circles; one of which he gave up to the Milanese astronomers (p. 504).This is the same instrument of which we spoke in vol. iv. p. 95 of this Correspondance, where we related the singular accident which happened to us with relation to it.

M. Méchain did not content himself with observing only the two circumpolar stars in Ursa Minor; he added two others, $\zeta$ Urse Majoris and a Draconis, and two zodiacal stars. The greatest differences are given in the following table: 


\begin{tabular}{|c|c|c|c|}
\hline $\begin{array}{l}\text { By the pole-star upper culm. } \\
\text { lower ditto }\end{array}$ & $\begin{array}{c}\text { Greatest } \\
\text { Differ. } \\
4, " 19 \\
4,46\end{array}$ & $\begin{array}{c}\text { Number } \\
\text { of Obs, } \\
186 \\
140\end{array}$ & $\begin{array}{c}\text { Base du } \\
\text { Syst. Mét } \\
\text { Vol. II. } \\
\text { p. } 558 \\
\text { p. } 5.58\end{array}$ \\
\hline Ву $\beta$ Urs $\alpha$ Minoris upper ditto & - 1,94 & 144 & p. 559 \\
\hline By \& Draconis $\quad$ lower ditto & $\begin{array}{l}7,14 \\
. \quad 3,70\end{array}$ & $\begin{array}{r}144 \\
72\end{array}$ & $\begin{array}{l}\text { p. } 559 \\
\text { p. } 560\end{array}$ \\
\hline By $\zeta$ Ursa Majoris upper ditto & $\begin{array}{l}\text { - } \quad 6,98 \\
\text { - } \quad 3,72\end{array}$ & $\begin{array}{l}72 \\
82\end{array}$ & $\begin{array}{l}\text { p. } 560 \\
\text { p. } 561\end{array}$ \\
\hline $\begin{array}{l}\text { By } \beta \text { Tauri } \\
\text { By } \beta \text { Geminorum }\end{array}$ & $\begin{array}{l}\cdot \quad 8,03 \\
\cdot \quad 5,90 \\
\cdot \quad 5,01\end{array}$ & $\begin{array}{l}82 \\
88 \\
40\end{array}$ & $\begin{array}{l}\text { p. } 561 \\
\text { p. } 562 \\
\text { p. } 562\end{array}$ \\
\hline
\end{tabular}

M. Méchain was never satisfied with his observations. M. Delambre said of him that he roas difficult to satisfy; but this excellent and scrupulous observer had good reason to be so, for he alone knew what he suppressed; he knew better than any body those irregularities which caused his despair. He said to all who talked with him on the subject, he wrote to his friends, he wrote even to M. Borda himself, who was then despotic in these operations, that with these circles he could not make observations even passably correct. This was the reason that M. Méchain wished to return to Spain to repeat his observations with other circles, and even at his own expense. M. Borda constantly opposed this project; and M. Delambre even went so far as to congratulate him on having succeeded in prevailing on $M$. Méchain to renounce all idea of it (p. 563). Being either less difficult, or more complaisant to M. Borda, he assures him that his latitude of Barcelona was, of all that had been observed up to that time, the most certain and the most solidly established, with the assistance of excellent instruments. But, we repeat, M. Méchain alone could estimate the excellence of his instruments; he alone could know the number of abortive observations, and the great number which it was necessary to reject. M. Delambre could not, therefore, be a competent judge of the labours of M. Méchain, which he knew only by a selection of according observations, without any knowledge of those which were put aside.

At Barcelona, M. Méchain observed nearly the same stars as at Montjouy; he added to their number Capella, which there passes the meridian within four degrees of the zenith. The greatest differences were

By the pole-star upper culm. lower ditto

$\begin{array}{ccc}\begin{array}{c}\text { Greatest } \\ \text { Differ. }\end{array} & \begin{array}{c}\text { Number } \\ \text { of Obs. }\end{array} & \begin{array}{c}\text { Base du } \\ \text { Syst. Mét. } \\ \text { Vol. II. }\end{array} \\ 2, " 21 & 104 & \text { p. 611 } \\ 1,69 & 104 & \text { p. 611 }\end{array}$




\begin{tabular}{|c|c|c|c|}
\hline $\begin{array}{c}\text { By } \beta \text { Ursa Minoris upper culm. } \\
\end{array}$ & $\begin{array}{c}\text { Greatest } \\
\text { Differ. } \\
3, \text {, } 69 \\
\text { 1. } 23\end{array}$ & $\begin{array}{c}\text { Number } \\
\text { of Obs. } \\
120 \\
108\end{array}$ & $\begin{array}{c}\text { Base du } \\
\text { Syst. Met. } \\
\text { Vol. II. } \\
\text { p. } 612 \\
\text { p. } 612\end{array}$ \\
\hline Ву $\zeta$ Ursa Majoris upper ditto & - $\quad 2,99$ & 80 & p. 613 \\
\hline $\begin{array}{l}\text { By Capricornus } \\
\text { By } \beta \text { Geminorum }\end{array}$ & $\begin{array}{r}3,25 \\
\cdot \quad 6,67 \\
. \quad 4,33\end{array}$ & $\begin{array}{r}80 \\
106 \\
104\end{array}$ & $\begin{array}{l}\text { p. } 613 \\
\text { p. } 614 \\
\text { p. } 614\end{array}$ \\
\hline
\end{tabular}

The fort of Montjouy is at the distance of only 1094 toises from Barcelona; indeed, of only $\mathbf{9 5 0}$ toises in the direction of the meridian. In reducing the latitudes observed in these two places to the same point, a difference appeared of $3^{\prime \prime}$, although 1728 observations had been made. This was the inexplicable difference which was the torment of M. Méchain to the end of his life, and as M. Delambre says (p. 617), the secret cause which had produced that earnest and SINGULAR (?!) desire of returning to Spain manifested by M. Méchain.

It is curious to read in the second volume of the Base Métrique (p. 617 et seq.) all the conjectures, all the hypotheses started by M. Delambre, to explain this incomprehensible difference of $3^{\prime \prime}$, and which, in fact, explain nothing at all.

But among all these hypotheses, M. Delambre passes over, or rather rejects, precisely that which, according to all likelihood, is the only true one. He says, "that he is perfectly convinced that the difference of $3^{\prime \prime}$ between Barcelona and Montjouy, ought not to be imputed to the observer." We have the same conviction; but we think that it might, with great justice, be imputed to the instruments. Of this M. Méchain was firmly persuaded, and this persuasion made him so earnestly desire to return to Spain; and when he found that an attempt was making to prevent his return, he wrote to M. Delambre; "If I had ever been able to take a decisive step, I should have gone, and have begun entirely anew, without consulting any body, and at my own expense" (p. 626). In another letter, in which he again speaks of his anxieties, and of the causes of his earnest desire of returning to Spain, he adds, "Have the goodness, I beg, to give this a moment's reflection; to confer about it with citizen Borda. I will take with me two circles, and two months at the utmost will be sufficient for my purpose. I am sure $I$ know the means of avoiding meny causes of errors and uncertainties," \&c. But M. Méchain received no other answer than this-That his project of returning to Barcelona appeared at once useless and impracticable, \&c.

In 1803, we procured from Paris the best repeating circles of Lenoir, which were at that time so much spoken of and praised. 
The Base Métrique had not then appeared; all the irregularities of which we have been speaking, and all the mortifications which these instruments had caused the French astronomers, were therefore unknown. We were at that time occupied in observing the latitude at the observatory of Seeberg, with a circle exactly similar to those with which MM. Delambre and Mćchain were labouring at the great meridian of France. These observations will be found registered in the 9 th volume, p. 292, of our Correspondance Astronomique Allemande, and it will there be seen, that the greatest differences we had in the latitudes served by us, were the following:

By the pole-star upper culm.

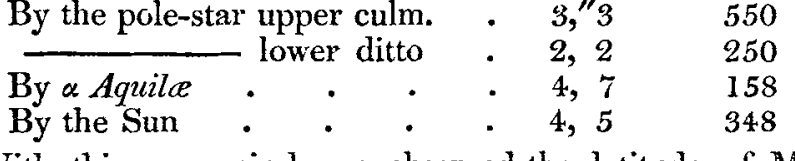

With this same circle we observed the latitude of Mont Brocken. These observations are to be found in the loth volume, p. 203, of the Corresp. Allemande. The greatest differences were

$$
\begin{aligned}
& \text { By the Sun . . . - } 4,{ }^{\prime \prime} 0 \quad 340 \\
& \text { By a Aquila } \quad \text {. } \quad . \quad \text {. } \quad \text {. } 3,6 \quad 188
\end{aligned}
$$

It appears by these experiments, that the anomalies which we found with these circles of Lenoir, were very nearly the same as those which the Parisian astronomers had encountered; they were rather less considerable than those remarked by M. Delambre, and equal to those experienced by M. Méchain at Barcelona; with this difference, that we have not withheld any of our observations, whilst M. Méchain rejected his by thousands, and selected such only as agreed the best.

In 1807 we were at Munich, where we became acquainted with the repeating circles of Reichenbach. With one of these circles of twelve inches diameter, we made our first essay on that instrument in the garden of M. Utzschneider, and we had the following differences:

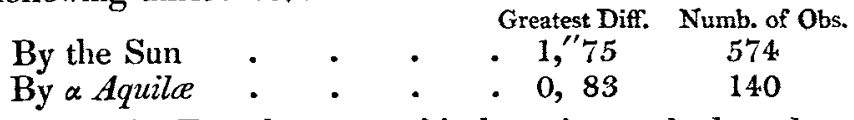

In 1802, the French geographical engineers had made a great triangulation in Bavaria with the repeating circles of Lenoir. M. Henry, at the same time, made 352 observations of latitude in the northern tower of Notre Dame. We went to the same tower with the circle of Reichenbach, and we there made nearly the same number of observations, which gave us

$\begin{array}{ccccc}\text { By the Sun . } & . & \cdot 1, " 37 & 358 \\ \text { Vol. 61. No. 301. May 1823. } & & Z_{Z} & & \text { In }\end{array}$

Greatest Diff. Numb. of Obs. 
In 1809 we passed through Milan. We there made, with the same circle of Reichenbach with which we had made our experiments at Munich, several observations at the Imperial Observatory of Brera; among others, that of the summer solstice. M. le Chevalier de Cesaris, the director of that observatory, made similar observations with the superb eight-foot mural quadrant of Ramsden. We had agreed to compare every day the apparent altitudes of the sun, which we observed with our respective instruments ; this comparison must consequently have given the errors of collimation of the mural circle, since it is well known that altitudes observed with the repeating circle are exempt from them. The following is the result:

Errors of Collimation of the Mural Circle.

$$
\begin{array}{r|r}
1809, \text { June } 11 \ldots \ldots+0,11 \\
13 \ldots \ldots-4,5 \\
14 \ldots \ldots-0,4 \\
15 \ldots \ldots-3,8 \\
17 \ldots \ldots-3,0
\end{array}
$$

These errors of collimation ought to be every day the same; nevertheless, they present anomalies which extend from zero to seven seconds. These irregularities ought, without doubt, to be distributed between the two observations; but to which

\begin{tabular}{|c|c|c|}
\hline $\begin{array}{l}\text { Milan, } \\
1809 .\end{array}$ & $\begin{array}{l}\text { Latitude given by } \\
\text { the Mural Circle } \\
\text { of Ramsden. }\end{array}$ & $\begin{array}{l}\text { Latitude given by } \\
\text { the Circle } \\
\text { of Reichenbach. }\end{array}$ \\
\hline $\begin{array}{r}\text { June } 11 \\
13 \\
14 \\
15 \\
17 \\
18 \\
19 \\
21 \\
22 \\
23 \\
25\end{array}$ & $\begin{array}{rr}45^{\circ} 27^{\prime} 60, " 2 \\
59,9 \\
56,3 \\
55,2 \\
58,1 \\
59,9 \\
59,0 \\
58,2 \\
60,5 \\
57,7 \\
62,2\end{array}$ & $\begin{array}{r}45^{\circ} 28^{\prime} 3, " 63 \\
3,29 \\
2,71 \\
2,50 \\
2,11 \\
1,95 \\
1,99 \\
2,01 \\
1,95 \\
2,17 \\
2,16\end{array}$ \\
\hline
\end{tabular}
of these instruments ought the greater part to be assigned, to the dwarf, or to the colossal instrument? The question is easy to decide. It was only necessary to compare the latitudes given by the two instruments. We have calculated them as follows:

The greatest difference in the mural circle of Ramsden amounts to $7^{\prime \prime}$, whilst in the repeating circle it amounts only to $1 ", 7$. 
In the years 1809 to 1813 inclusive, we made more than 8000 -observations at Marseilles and in the South of France with this same circle of Reichenbach; but we will only refer to those which we have already published either in our Correspondance Astronomique Allemande, or in our work L'Attraction des Montagnes, \&c.

The table of the observations is as follows:

At the Royal Observatory at Marseilles:

$$
\begin{gathered}
\text { Greatest Number Attr. des } \\
\text { Diff. Of Obs. Montag. }
\end{gathered}
$$

By the pole-star upper culm. - 2,"59 300 p. 414

$\begin{array}{lllll}\text { upper culm. } & \cdot 2, " 59 & 300 & \text { p. } 414 \\ \text { lower ditto } & \cdot & 3,29 & 280 & \text { p. } 414\end{array}$

At the Observatory of St. Peyre :

By the pole-stax upper culm. . 3, $46 \quad 238 \quad$ p. 416

- lower ditto . 2,33 210 p. 415

By $\beta$ Urse Minoris upper ditto $\quad$. I, $81 \quad 150 \quad$ p. 416 At the Observatory of La Capelette:

By the pole-star lower culm. . 3, 16 314 p. 419 At Notre-Dame des Anges:

By a Serpentis . . • . 3, $42 \quad 300$ p. 100

By $\zeta$ Aquila $\quad$. . . . 4, 40 450 p. 101

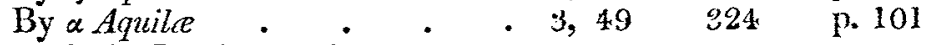

At the Isle de Planier:

$\begin{array}{lllllll}\text { By } \alpha \text { Serpentis } & \text {. } & \text {. } & \text { • } & \text {. 2, } 47 & 298 & \text { p. } 202\end{array}$

By $\zeta$ Aquila $\quad \cdot \quad$. $\quad . \quad$. 2, $44 \quad 268$ p. 202

By a Aquile $\quad \cdot \quad \cdot \quad \cdot \quad \cdot \quad 1,84 \quad 330 \quad$ p. 202

It appears by this exposé, that in 3262 observations, not selected, made with a small 12-inch repeating circle of Reichenbach, the greatest difference in these observations, from day to day, never extended beyond $4^{\prime \prime}$ in the altitudes; but if we seek these differences in a combination of the series, they never exceeded two seconds.

[To be continued.]

LXXIV. True apparent Right Ascension of Dr.MASKeLYNE's 36 Stars for every Day in the Year 1823, at the Time of passing the Meridian of Greenwich.

[Continued from page 247.$]$

N.B. On those days where an Asterisk is prefixed the Star passes twice; the $\mathbb{R}$ given is that at the first passage. 